ZBIGNEW ZIOt0

Uniwersytet Pedagogiczny w Krakowie, Polska - Pedagogical University of Cracow, Poland

\title{
Przedsiębiorczość w rozwoju układów lokalnych
}

\section{Entrepreneurship in the Development of Local Systems}

Streszczenie: Wstępnie zakładamy, że w procesie rozwoju cywilizacyjnego przedsiębiorczość jest jednym z podstawowych czynników wzrostu gospodarczego, społecznego i kulturowego. Proces ten, w zależności od uwarunkowań wewnętrznych i otoczenia, ze zmiennym nasileniem kształtuje układy przestrzenne od skali krajowej przez układy regionalne do układów lokalnych. Wychodząc z powyższego założenia, należy przyjąć, że szczególnie ważnym problemem badawczym jest dążenie do coraz precyzyjniejszego poznania złożoności procesu kształtowania samorządowych układów lokalnych. Wyniki badawcze z tego zakresu mają także duże znaczenie dla celów aplikacyjnych, zwłaszcza w zakresie podnoszenia jakości zarządzania i budowy strategii rozwoju tej kategorii układów. W niniejszej pracy podjęta została analiza wpływu przedsiębiorczości na proces funkcjonowania układów lokalnych z uwzględnieniem wewnętrznych i zewnętrznych uwarunkowań rozwoju.

\begin{abstract}
It should be initially assumed that in the process of the civilization development, entrepreneurship is one of the main drives of economic, social and cultural growth. This process, depending on internal conditions and the environment, with varying intensity shapes the spatial systems - from national scale through regional systems to local systems. Proceeding from this assumption it should be noted that a particularly important research problem is to strive for more and more precise knowledge of the complexity of the process of formation of local self-government system. The results of the research in this field are also important for the application purposes, especially in improving the quality of management and creating of the development strategy of this category of systems. The study was undertaken to analyse the impact of entrepreneurship on the process of functioning of local systems, taking into account internal and external conditions of development.
\end{abstract}

Słowa kluczowe: gmina; przedsiębiorczość; układ lokalny

Keywords: entrepreneurship; local system; municipality

Otrzymano: 2 lutego 2016

Received: 2 February 2016

Zaakceptowano: 31 maja 2016

Accepted: 31 May 2016

\section{Sugerowana cytacja/Suggested citation:}

Zioło, Z. (2016). Przedsiębiorczość w rozwoju układów lokalnych. Przedsiębiorczość - Edukacja, $12,6-17$. 
Wstęp

Kształtowanie przedsiębiorczości w układach lokalnych jest procesem złożonym, który powinien nawiązywać do ogólnego procesu rozwoju cywilizacyjnego. Podstawową rolę w tym zakresie odgrywa nauka, umożliwiająca kształtowanie gospodarki opartej na wiedzy. Wymaga to stwarzania w przestrzennych strukturach społecznych, gospodarczych i kulturowych odpowiednich warunków dla rozwijania myślenia i działania innowacyjnego. Duże znaczenie ma tu edukacja, upowszechniająca w procesie dydaktycznym kształtowanie postaw przedsiębiorczych oraz umiejętności działania w zmieniającym się otoczeniu. W podejmowanych działaniach należy zwracać uwagę na fakt, że w najbliższych latach przedsiębiorstwa w coraz większym stopniu konkurować będą jakością oferowanych produktów, a w mniejszym stopniu - niskimi kosztami pracy. Warunkiem koniecznym dla podnoszenia konkurencyjności oferowanych produktów jest stawianie na badania, rozwój oraz innowacje, a następnie umiejętność komercjalizacji osiągnięć naukowo-badawczych. Należy uwzględnić, że wiele początkowo niewielkich firm lokalnych przekształca się w firmy o znaczeniu międzynarodowym ${ }^{1}$. Dlatego konieczna jest stopniowa zmiana dominującego obecnie modelu gospodarki naśladowniczo-montażowej, w którym preferuje się proste, niskopłatne stanowiska pracy na rzecz gospodarki innowacyjnej, także w strukturach układów lokalnych. Ten typ gospodarki nie wykorzystuje w pełni kompetencji zawodowych i w niewielkim stopniu zaspokaja ambicje oraz oczekiwania, zwłaszcza dobrze wykształconych, młodych ludzi. Jak twierdzi Czapiński (2015), „najważniejszym problemem polskiego rynku pracy staje się rosnąca przepaść między kompetencjami i ambicjami zawodowymi, zwłaszcza młodych rodaków a charakterem gospodarki”.

Wagę podjętej problematyki podkreśla fakt, że w gospodarce narodowej przedsiębiorczość traktowana jest jako jeden z podstawowych czynników wzrostu gospodarczego, społecznego i kulturowego układów lokalnych i regionalnych, a także układu krajowego (Brdulak, Kulinowski, 2004; Czarnecka, Kłodziński, 2010; Fierla, 1994, 1996; Fierla, Kuciński, 1999; Kamińska, 2006; Kamińska, Heffner, 2012, Kudełko, 2013; Płaziak, Rachwał, 2015). Dlatego $\mathrm{w}$ procesie zarządzania jako podstawowe zadanie należy przyjąć dążenie, aby w układach lokalnych rozwijała się aktywność indywidualna, wzrastał stopień zaufania, który stanowi ważną przesłankę rozwijania zasobów kapitału społecznego oraz pozwala na szersze otwieranie się na współpracę i łączenie swoich celów rozwojowych z otoczeniem (Debelle i in., 1996; Fircowicz i in., 1996; Kamińska, Heffner, 2010; Zioło, 2010, 2012). Proces ten, w zależności od uwarunkowań wewnętrznych i uwarunkowań otoczenia, przebiega ze zmiennym nasileniem i kształtuje także układy lokalne, w których znacząca rolę odgrywają jakość i poziom władz samorządowych. W działaniach edukacyjnych należy propagować nowe myślenie, które prowadzić będzie do kształcenia umiejętności zachowań konkurencyjnych, w drodze wdrażania nowych produktów wynikających z innowacyjnych rozwiązań technicznych, ekonomicznych i organizacyjnych. Oznacza to, że zamiast oszczędzać na niskich płacach, należy inwestować w podnoszenie kwalifikacji zawodowych pracowników. Należy zaznaczyć, że firma swoją konkurencyjność może podnieść nie przez innowacje, ale przez niskie koszy pracy i zatrudnianie

${ }^{1}$ Przykładem jest podwarszawska firma Createch. Jej współzałożycielem i obecnie prezesem jest dr fizyki Grzegorz Brona, który jest dostawcą sprzętu dla ESA (Europejskiej Agencji Kosmicznej), w tym elementów Międzynarodowej Stacji Kosmicznej. Dzięki niej powstaje w Polsce unikatowy system przechowywania i przetwarzania danych pochodzących z satelitów, a firma wykształciła się jako najprężniejszy podmiot polskiego sektora kosmicznego (Stanisławska, 2016). 
na czas określony, przy znacznej rotacji pracowników. Są to jednak korzyści doraźne i krótkotrwałe, które w dłuższej perspektywie osłabią firmę. Należy proponować zakładanie firm, które w coraz większym stopniu będą rozwijać swoją działalność i stopniowo rozszerzać swoje rynki od lokalnych po międzynarodowe ${ }^{2}$. W wyniku braku takiego podejścia wiele programów rozwoju lokalnego i regionalnego napotyka na poważne trudności i w konsekwencji ich realizacja załamuje się lub nie daje zakładanych wcześniej wyników ekonomicznych, co z kolei w słabym stopniu wpływa na podnoszenie poziomu i jakości życia ludności. W pewnej mierze jest to związane $z$ uwzględnieniem tylko wybranych cech ekonomicznych czy technicznych, przy braku pełnego rozeznania i całościowego ujęcia tej problematyki. Przejawia się to w podejmowaniu decyzji o budowie wielu obiektów, które nie przynoszą zakładanych korzyści, a czasem ich utrzymanie staje się kłopotem.

Szczególnie ważnym problemem badawczym jest zatem dążenie do coraz precyzyjniejszego poznania złożoności procesu, funkcjonowania i kształtowania samorządowych układów lokalnych, a także ponadlokalnych i regionalnych. Niezbędne wydaje się wypracowywanie koncepcji teoretycznych, a następnie ich weryfikacja empiryczna, mająca na celu całościowe ujęcie funkcjonowania i rozwoju podmiotów gospodarczych w układach lokalnych. Wyniki badawcze z tego zakresu mają więc duże znaczenie aplikacyjne, a studia diagnostyczne są konieczne dla racjonalnego zarządzania układami lokalnymi oraz budowy strategii ich rozwoju z uwzględnieniem współczesnych tendencji przemian i reguł efektywności społecznej oraz ekonomicznej.

Znaczące osiągnięcia badawcze w zakresie przemian układów lokalnych prezentowali autorzy prac wykonanych w ramach byłego Komitetu Badań Rejonów Uprzemysławianych przy Prezydium PAN. Przedmiotem badań były przemiany społeczno-gospodarcze i kulturowe dokonujące się pod wpływem wielkich inwestycji przemysłowych, które wpłynęły na kształtowanie się nowych okręgów przemysłowych (Ignar, 1962), m.in. Tarnobrzeskiego Okręgu Siarkowego (Dobrowolska, 1968; Zioło, 1978), Okręgu Miedziowego (Golachowski, Zagożdżon, 1974) i Okręgu Płockiego (Lachert, Dembrowska, 1973).

\section{Lokalizacja i funkcje firm układu lokalnego}

Samorządowe układy lokalne reprezentowane przez gminy miejskie, miejsko-wiejskie i wiejskie odznaczają się bardzo dużym zróżnicowaniem pod względem historycznego procesu rozwoju, zasobów potencjału społeczno-gospodarczego i kulturowego, położenia w strukturze sieci osadniczej oraz spełnianych funkcji. Są one w różnym stopniu atrakcyjne dla lokalizacji i rozwoju działalności podmiotów gospodarczych i instytucji oraz kształtowania określonych funkcji w układzie lokalnym (Fierla, Kuciński, 1999; Rachwał, 2008, 2009, 2013; Zioło, Rachwał, 2015). W konsekwencji możliwości rozwoju działalności usługowej i produkcyjnej w układach lokalnych są złożone (tab. 1).

\footnotetext{
${ }^{2}$ Sanocka Fabryka Autobusów wykształciła się z warsztatu założonego w 1832 r. przez uczestników powstania listopadowego, którzy w obawie przed prześladowaniami schronili się w zaborze austriackim. Swoją działalność rozpoczęli od wytwarzania prostych narzędzi na potrzeby gospodarstw rolnych. Następnie jeden z właścicieli wysłał swojego syna na studia politechniczne do Wiednia, co doprowadziło do zmiany profilu produkcji i dało początek obecnej fabryce (Gajewski, Świdrak, 1962). Również z firmy ponadlokalnej rozwinęła się światowa firma informatyczna Asseco Poland S.A., którą założył i którą kieruje dr A. Góral, były adiunkt Wydziału Ekonomicznego Filii UMCS w Rzeszowie.
} 
Tab. 1. Funkcje i lokalizacja wybranych typów firm układów lokalnych

\begin{tabular}{|c|c|c|}
\hline \multirow{13}{*}{ Usługowe } & \multirow{8}{*}{$\begin{array}{l}\text { obsługa } \\
\text { ludności }\end{array}$} & warszaty: samochodowe, ślusarskie, elekryczne \\
\hline & & instalacje i naprawa sprzętu gospodarstwa domowego \\
\hline & & obsługa finansowa, porady prawne \\
\hline & & handlowe i gastronomiczne \\
\hline & & $\begin{array}{l}\text { usługi oświatowe (dokształcanie i kształcenie zawodowe, } \\
\text { przedszkola, szkoły, nauka języków i in.) }\end{array}$ \\
\hline & & usługi zdrowotne (żłobki, przychodnie, apteki) \\
\hline & & usługi kulturalne (domy kultury, świetlice) \\
\hline & & inne \\
\hline & \multirow{5}{*}{$\begin{array}{l}\text { obsługa } \\
\text { rolnictwa }\end{array}$} & upraw polowych \\
\hline & & upraw warzyw i owoców \\
\hline & & \begin{tabular}{|l|} 
usługi weterynaryjne \\
\end{tabular} \\
\hline & & $\begin{array}{l}\text { usługi agrotechniczne (upraw: zbożowych, przemysłowych, } \\
\text { warzyw, sadów) }\end{array}$ \\
\hline & & naprawa i remonty sprzętu \\
\hline \multirow[t]{12}{*}{ Produkcyjne } & \multirow{2}{*}{$\begin{array}{l}\text { produkcja } \\
\text { rolnicza }\end{array}$} & zbóż, roślin przemysłowych, pastewnych, warzyw, owoców i in. \\
\hline & & hodowla zwierząt gospodarskich \\
\hline & \multirow{2}{*}{$\begin{array}{l}\text { przetwórstwo } \\
\text { produktów } \\
\text { rolniczych }\end{array}$} & zbóż, roślin przemysłowych, pastewnych, warzyw, owoców i in. \\
\hline & & produkcja mięsna i przetworów \\
\hline & \multirow{4}{*}{$\begin{array}{l}\text { produkcja } \\
\text { wyrobów }\end{array}$} & konsumpcyjnych (piekarnie, masarnie, mleczarnie i in.) \\
\hline & & wyposażenie mieszkań \\
\hline & & codziennego użytku \\
\hline & & $\begin{array}{l}\text { produkcja finalna lub elementów w ramach kooperacji } \\
\text { z dużymi firmami }\end{array}$ \\
\hline & \multirow{2}{*}{\begin{tabular}{|l|} 
firmy \\
budowlane
\end{tabular}} & budowlane \\
\hline & & instalacyjne \\
\hline & \multicolumn{2}{|c|}{ produkcja wyrobów artystycznych (koronkarstwo, pamiątki) } \\
\hline & \multicolumn{2}{|c|}{ eksploatacja zasobów naturalnych (mineralnych, wodnych i in.) } \\
\hline \multirow{8}{*}{$\begin{array}{l}\text { Główne czynniki } \\
\text { rozwoju firm }\end{array}$} & \multicolumn{2}{|c|}{ kwalifikacje właściciela i pracowników } \\
\hline & \multicolumn{2}{|c|}{ rynek produktów i usług (od lokalnego po międzynarodowy) } \\
\hline & \multicolumn{2}{|c|}{ własne zasoby finansowe } \\
\hline & \multicolumn{2}{|c|}{ jakość instytucji i stabilność instrumentów finansowych } \\
\hline & \multicolumn{2}{|c|}{ organizacja działalności gospodarczej } \\
\hline & \multicolumn{2}{|c|}{ pomoc instytucjonalno-prawna } \\
\hline & \multicolumn{2}{|c|}{ lokalny klimat dla rozwoju działalności gospodarczej } \\
\hline & \multicolumn{2}{|c|}{ zagospodarowanie infrastrukturalne } \\
\hline \multirow{3}{*}{$\begin{array}{l}\text { Położenie w sieci } \\
\text { osadniczej }\end{array}$} & \multicolumn{2}{|c|}{ dużych miast } \\
\hline & \multicolumn{2}{|l|}{ średnich miast } \\
\hline & \multicolumn{2}{|l|}{ małych miast } \\
\hline \multirow{5}{*}{$\begin{array}{l}\text { Położenie na } \\
\text { obszarach }\end{array}$} & \multicolumn{2}{|l|}{ nizinnych } \\
\hline & \multicolumn{2}{|l|}{ nadmorskich } \\
\hline & \multicolumn{2}{|l|}{ pojeziernych } \\
\hline & podgórskich & \\
\hline & górskich & \\
\hline
\end{tabular}

Źródło: opracowanie własne 
Funkcje usługowe podmiotów gospodarczych i instytucji nawiązują najczęściej do potrzeb lokalnych i ponadlokalnych, a ich rozmiary bardzo silnie zależą od zasobów finansowymi ludności, które stwarzają określone rozmiary rynku. Zgodnie z regułami rynku, wzrost zasobów finansowych stwarza korzystne warunki dla rozwoju działalności usługowej, natomiast kurczące się zasoby wpływają na jej ograniczanie. W strukturze podmiotów działalności usługowej wyróżniają się usługi związane z obsługą ludności i rolnictwa. Wśród nich ważną rolę odgrywają warsztaty naprawcze, co jest związane z postępującym procesem upowszechniania środków transportu oraz coraz powszechniejszym stosowaniem sprzętu elektrycznego i elektronicznego w gospodarstwach domowych. Należy wnosić, że proces ten będzie się nasilał i stwarzał korzystne warunki dla rozwoju tego typu usług. Prowadzenie działalności gospodarczej tworzy także korzystne warunki dla rozwoju obsługi finansowej i prawnej, zwłaszcza wynikających z czasem niejasnych i zmieniających się zasad opodatkowania oraz reguł prowadzenia działalności gospodarczej³. Dla właściwego funkcjonowania układu lokalnego ważne są usługi instytucji oświatowych, zdrowotnych i kulturowych, zwłaszcza związane z formami spędzania wolnego czasu młodzieży.

Funkcjonowanie układów lokalnych związane jest z działalnością rolniczą, co w wielu wypadkach wymaga specjalistycznej wiedzy z zakresu upraw, hodowli i usług weterynaryjnych, specjalistycznych usług agrotechnicznych oraz napraw i remontów coraz bardziej złożonego sprzętu rolniczego.

Nowoczesne rolnictwo towarowe stwarza dogodne warunki dla rozwoju przemysłu rolno-spożywczego i magazynowania produktów. Wobec rosnącej świadomości społecznej i poszukiwania zdrowej żywności, przy wzroście zasobów finansowych ludności, produkcja tego typu może być ważnym czynnikiem rozwoju gospodarczego układu lokalnego. Reguły konkurencyjności oraz konieczność produkcji coraz wartościowszych produktów rolniczych wymagają jednak nowej organizacji działalności opartej na wiedzy z zakresu rolnictwa, prawa czy finansów. Stwarza to możliwości powstawania nowoczesnych form działalności w postaci kompleksów rolniczo-przetwórczych, a przy wykorzystaniu odpadów - także kompleksów agro-przetwórczo-energetycznych (Maj, Zioło, 1991; Maj, Woźniak, Zioło, 2010; 2012). Należy zaznaczyć, że ta nowa forma gospodarowania może przyczynić się do podnoszenia jakości kapitału ludzkiego i konieczności współdziałania, sprzyjać będzie także rozwojowi kapitału społecznego.

$\mathrm{Na}$ obszarze układu lokalnego mogą występować dobre warunki dla lokalizacji różnego rodzaju firm przemysłowych. Mogą one prowadzić produkcję na potrzeby rynku lokalnego czy regionalnego, rozwijać się na podstawie powiązań kooperacyjnych z dużymi korporacjami światowymi czy pracować wprost na potrzeby rynku międzynarodowego. Ma to szczególne znaczenie wobec możliwości wykonywania pracy na odległość.

Podstawowymi czynnikami rozwoju działalności produkcyjno-usługowej w układach lokalnych są poziom wykształcenia społeczeństwa i kwalifikacje pracownicze zdobyte na różnych poziomach edukacji: od przyuczenia zawodowego przez szkolnictwo zawodowe i średnie techniczne po wykształcenie wyższe. Szczególnie ważnym zagadnieniem dla władz samorządowych jest więc stwarzanie warunków powrotu do miejsca zamieszkania osób zdobywających kwalifikacje i doświadczenie zawodowe w zakresie prowadzenia działalności w otoczeniu

${ }^{3}$ Wiele trudności $\mathrm{w}$ prowadzeniu działalności gospodarczej stwarzają zmieniające się instrumenty prawne (zob. Możyłowski, 2013). Charakteryzują się one niską jakością, z czym wiążą się zbyt częste nowelizacje nie zawsze uwzględniające realia biznesowe (Nowak, 2015). Od przystąpienia Polski do Unii Europejskiej weszło w życie ponad 200 tys. stron nowych przepisów, a w 2014 r. ponad 25 tys. aktów prawnych (dmp, 2015) . 
regionalnym, krajowym czy międzynarodowym. Dla rozwoju działalności ważne są: rozmiary rynku dla oferowanych produktów oraz możliwości jego pogłębiania i rozszerzania, jakość instytucji finansowych i stabilność instrumentów prawnych, organizacja działalności gospodarczej, pomoc instytucjonalno-prawna, sprzyjający klimat układu lokalnego. Czynnikiem rozwoju mogą być także lokalne tradycje rzemieślnicze, pozwalające na produkcję wyrobów regionalnych, oraz jakość i wielkość miejscowych zasobów surowców (mineralnych, rolniczych), które umożliwiają ich wytwarzanie, eksploatację czy przetwarzanie na potrzeby różnych kategorii rynków: od rynków lokalnych, przez regionalne, krajowe, po rynki międzynarodowe.

Odmienne możliwości rozwoju daje układom lokalnym położenie w różnych miejscach sieci osadniczej. Inne możliwości lokalizacji i rozwoju mają podmioty gospodarcze układów lokalnych funkcjonujące w zapleczu dużych ośrodków miejskich, inne - w zapleczu ośrodków średnich i małych, a jeszcze inne - położone $z$ dala od nich.

Różne możliwości rozwoju układom lokalnym i występujących na ich terenie podmiotom gospodarczych i instytucji stwarza również ich położenie w strukturze przestrzeni przyrodniczej, np. w górach, na wyżynach, nad morzem czy w krainie jezior, lasów. Daje ono odmienne możliwości rozwoju funkcji produkcyjnych, usługowych, turystycznych, rekreacyjno-zdrowotnych i in.

\section{Miejsce przedsiębiorstwa w strukturze układu lokalnego}

W procesie kształtowania i rozwoju podmiotów gospodarczych podstawowe znaczenie mają uwarunkowania wnikające zarówno z rodzaju i spełnianych przez dane przedsiębiorstwo funkcji, jak i ze zmieniających się uwarunkowań wewnętrznych w strukturze układu lokalnego oraz uwarunkowań wynikających z otoczenia. Głównymi czynnikami w tym zakresie są: poziom techniczny, źródła finansowania działalności, jakość obsługi finansowej i możliwości kredytowania, zagospodarowanie infrastrukturalne, jakość i przychylność władz samorządowych, które w znaczącym stopniu mogą wpływać na obniżania kosztów działalności i podnoszenia efektywności ekonomicznej. W wyniku decyzji władzy lokalnej czy centralnej można rozważać także efektywność społeczną, którą można uzyskać w wyniku: dotacji, subwencji, zwolnień podatkowych czy zwolnień z opłat, poprawienie jakości infrastruktury technicznej i in., czego przykładem mogą być także specjalne strefy ekonomiczne (tab. 2).

Układ lokalny może więc stwarzać korzystne lub mniej korzystne warunki dla lokalizacji i rozwijania działalności. Podstawowe znaczenie mają tu jakość zasobów wiedzy władzy samorządowej i klimat społeczny, który może tworzyć korzystne warunki lokalizacji i rozwoju działalności m.in. przez umożliwienie przejęcia składników rzeczowych w postaci środków trwałych, najczęściej powstałych w warunkach gospodarki centralnie sterowanej, a w nowych warunkach niezagospodarowanych, wyznaczanie nowych terenów dla lokalizacji działalności gospodarczej, podnoszenie poziomu zagospodarowania infrastrukturalnego i in.

Dla firm o funkcjach lokalnych duże znaczenie ma otoczenie ponadlokalne, które może generować mechanizmy konkurencji dla oferowanych produktów i usług, wpływać na pogłębianie i rozszerzanie rynków zbytu produktów i usług, wpływać na możliwości dostępności obszarów zaopatrzenia, tworzyć odpowiednio korzystną politykę gospodarczą oraz poprawne i stabilne instrumenty prawne dla prowadzenia działalności. 


\begin{tabular}{|c|c|c|c|c|c|c|c|c|c|c|c|}
\hline 氞吾递 & ن & is & $\stackrel{0}{\Sigma}$ & $\stackrel{י}{S}$ & $\stackrel{0}{*}$ & ڤ̆ & $\mid \begin{array}{c}0 \\
\approx\end{array}$ & $\stackrel{\varphi}{\infty}$ & 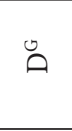 & $\mid$ & ن \\
\hline 苞言 & -1 & $\omega$ & $\vec{\Sigma}$ & $\vec{b}$ & $\vec{z}$ & $\vec{A}$ & $\vec{\sim}$ & $\vec{\infty}$ & $\overrightarrow{0}$ & $\exists$ & ن \\
\hline 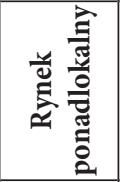 & a & कि & $\stackrel{\Sigma}{\Sigma}$ & 今 & 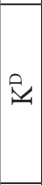 & مิ & $\ddot{\approx A}$ & के & คิ & 光 & نि \\
\hline 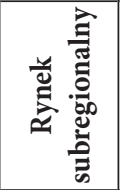 & $\infty$ & क & $\sum_{\Sigma}^{\infty}$ & 今े & $\stackrel{\infty}{i}$ & คै, & $\approx 0$ & దै & คै & ص & )ै \\
\hline 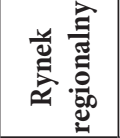 & $\simeq$ & $\approx$ & $\stackrel{n}{\Sigma}$ & 䒓 & $\underline{z}$ & 苂 & $\approx z$ & ฉี & ڤี & 响 & 凹̋ \\
\hline 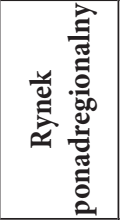 & 2 & is & $\ddot{\Sigma}$ & $\hat{5}$ & $\frac{2}{2}$ & مै, & $\ddot{\approx}$ & $\tilde{\infty}$ & $\tilde{\mid}$ & 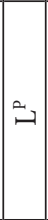 & ச \\
\hline 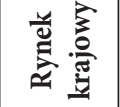 & $\approx$ & 范 & 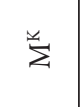 & 㕺 & 竧 & 光 & $\ddot{z}$ & 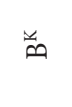 & 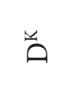 & $\stackrel{\square}{\sim}$ & ש \\
\hline 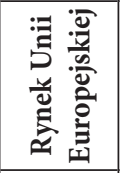 & $P$ & is & $\sum$ & 名 & $\frac{R}{2}$ & ฉ & 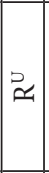 & $D_{n}$ & $\stackrel{\circ}{\circ}$ & 记 & 己 \\
\hline 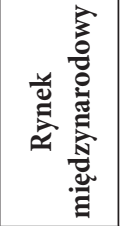 & $\Sigma$ & $\Sigma$ & $\sum_{\Sigma}^{\Sigma}$ & 苔 & $\underline{\Sigma}$ & 苔 & $\mid \begin{array}{l}\sum_{\sim 1} \\
\mid\end{array}$ & $\sum_{\infty}$ & 芒 & 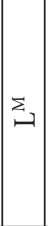 & 心 \\
\hline 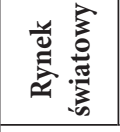 & $\infty$ & $\infty$ & $\sum_{\Sigma}^{\infty}$ & $\stackrel{s}{b}$ & $\ddot{v}$ & מ̆ & $\tilde{\sim}$ & מ & مै & $\stackrel{0}{n}$ & $\stackrel{0}{0}$ \\
\hline \multirow[b]{2}{*}{ 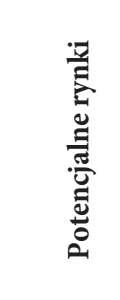 } & & $\infty$ & $\Sigma$ & $\triangleright$ & $\triangle$ & $a$ & $\simeq$ & $ص$ & D & 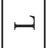 & $\bullet$ \\
\hline & & 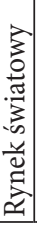 & 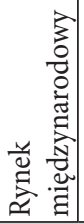 & 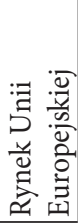 & 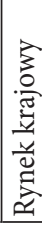 & 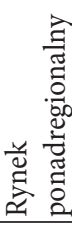 & 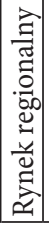 & 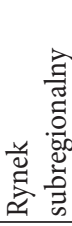 & 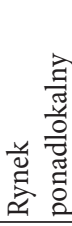 & 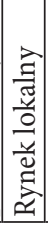 & 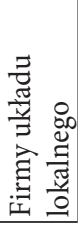 \\
\hline
\end{tabular}


Właściwie funkcjonujące i rozwijające się przedsiębiorstwa stwarzają dla układu lokalnego określone korzyści ekonomiczne (podatki, dostosowanie infrastruktury technicznej do potrzeb przedsiębiorstwa, przy czym korzysta z niej także społeczeństwo), społeczne (aktywizacja zawodowa bezrobotnych, możliwości podnoszenia czy zdobywania kwalifikacji zawodowych, zwiększanie strumieni finansowych płynących do gospodarstw domowych) i kulturowych (podnoszenie kultury osobistej w nowym miejscu pracy, organizacja i wspieranie działalności artystycznej, sportowej i in.).

Analityczny obraz funkcjonowania przedsiębiorstwa w układzie lokalnym bardziej precyzyjnie określa czynniki rozwoju przedsiębiorstwa w układzie lokalnym i zwraca uwagę na podstawowe składniki kosztów uzyskania przychodów, źródła finansowania oraz rynki zaopatrzenia i zbytu (tab. 3).

Tab. 3. Miejsce przedsiębiorstwa w układzie lokalnym

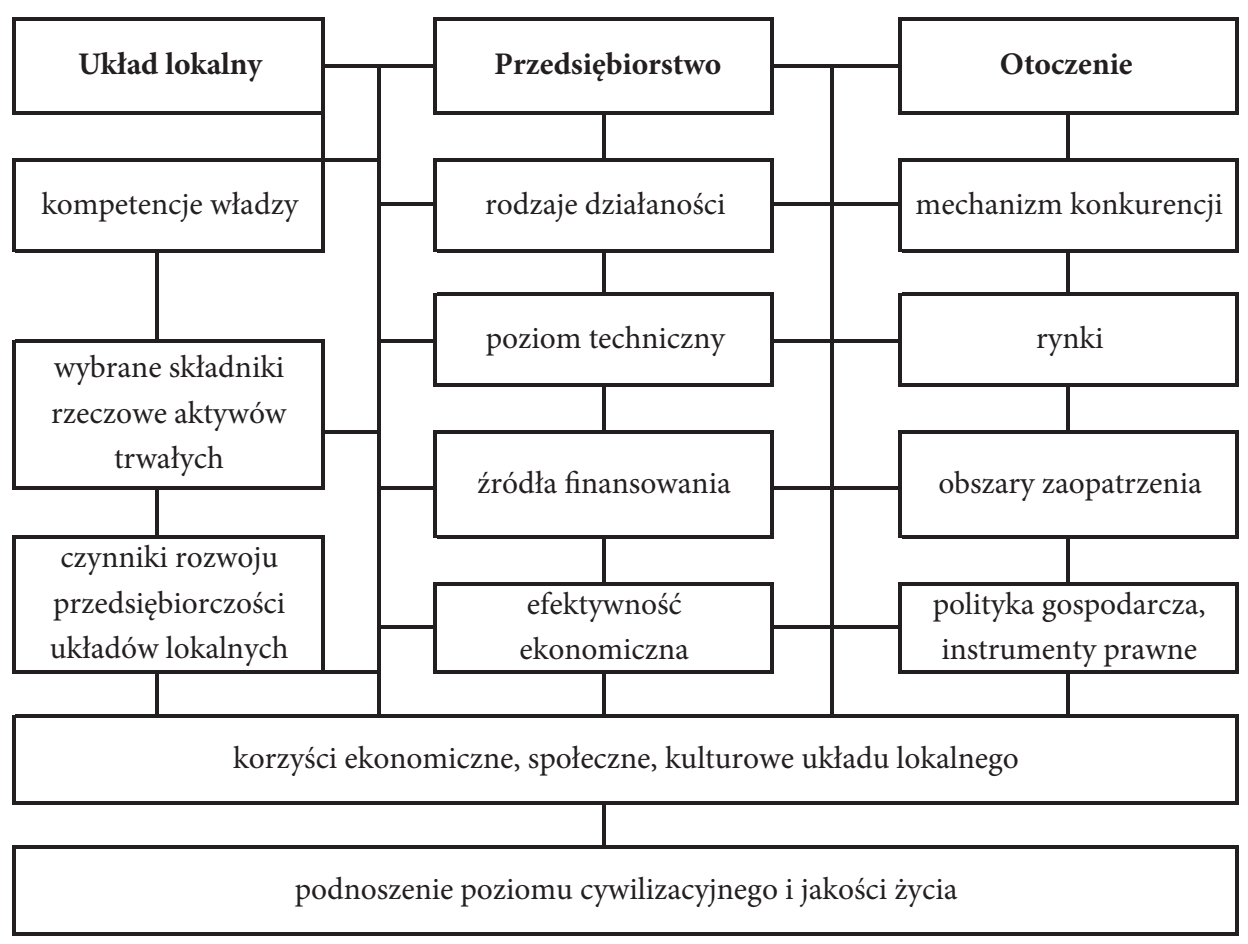

Źródło: opracowanie własne

W zależności od potrzeb analitycznych poszczególne elementy można określić bardziej szczegółowo (np. które działania polityki gospodarczej czy instrumenty prawne umożliwiają rozwój, ograniczają czy uniemożliwiają prowadzenie działalności gospodarczej). Duży wpływ na zachowania przedsiębiorstw w układzie lokalnym mają zasoby finansowe ludności i instytucji, umożliwiające zwiększanie chłonności rynku. Istotna dla rozwoju działalności gospodarczej jest także znajomość funkcjonowania podmiotów gospodarczych w konkretnych uwarunkowaniach lokalnych. Stąd często decyzje lokalizacyjne podejmowane przez właścicieli 


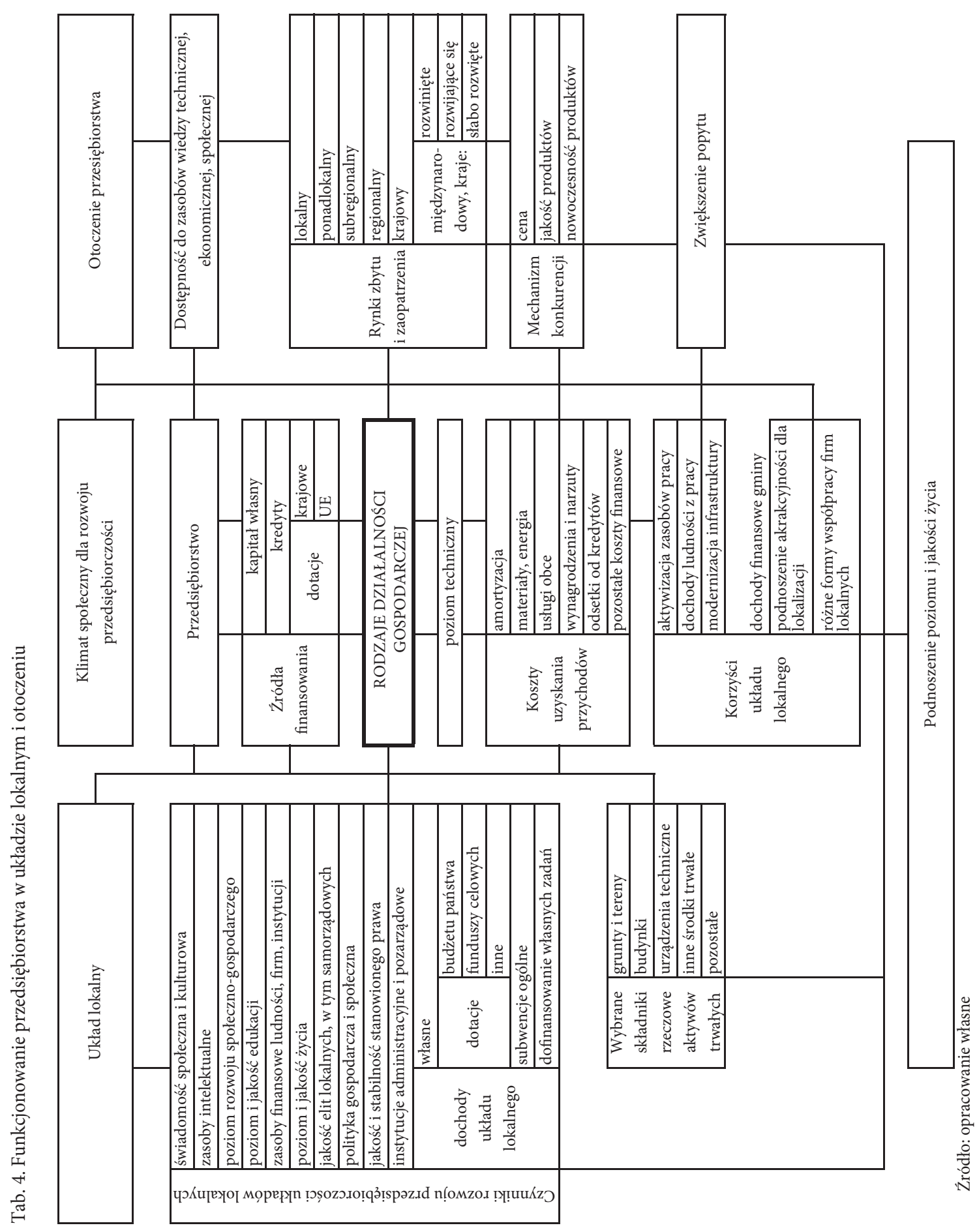


nie zawsze dają zadawalające rezultaty i często prowadzą do zaniechania działalności gospodarczej. Na zmieniające się uwarunkowania funkcjonowania i rozwoju działalności gospodarczej w znacznym stopniu wpływają również pozytywne lub negatywne impulsy płynące z otoczenia ${ }^{4}$ (tab. 4).

Należy zaznaczyć, że różne typy przedsiębiorstw muszą spełniać określone warunki dla prowadzenia działalności gospodarczej i kształtować odpowiednie relacje z otoczeniem. Przykładowo zakłady mięsne poddawane są kontroli i muszą spełniać określone normy sanitarne oraz normy dotyczące wyposażenia technicznego, dzięki czemu produkcja może być kierowana na rynek lokalny, krajowy i międzynarodowy. Na tej podstawie określa się ich możliwości produkcyjne przez przyznawanie im określonych wielkości jednostek ubojowych.

Przy skupie zwierząt z gospodarstw domowych przez przedstawicieli zakładów mięsnych wymagane są świadectwa zdrowia zwierząt wydawane przez lekarza weterynarii, dokonuje się kontroli zgodności oznakowania zwierząt $\mathrm{z}$ wpisami w świadectwie zdrowia oraz ocenia się ich klasę, co wpływa na podnoszenie kultury rolnej gospodarstw domowych. Zakłady mleczarskie wymagają określonej klasy mleka o ustalonej liczebności kultur bakteryjnych, co umożliwia produkcję określonych wyrobów.

Podobnie przy dostawach owoców i warzyw dla przemysłu przetwórczego dokonywana jest ich kontrola pod względem zawartości substancji chemicznych, które mogą wynikać z obfitego stosowanie nawozów czy nadmiernej częstotliwości stosowania środków ochrony roślin.

Działania te nasilają powiązania gospodarstw rolniczych z zakładami przemysłowymi, dzięki czemu wpływają na podnoszenie poziomu kultury produkcji rolniczej, stosowanie określonych zasad upraw i hodowli, utrzymanie reguł sanitarnych oraz jakości oferowanego surowca. Niezbędne jest w tym zakresie ciągle doskonalenie wiedzy i umiejętności, a także korzystanie z usług weterynaryjnych, sanitarnych i agrotechnicznych. Nasila to konieczność racjonalnego współdziałania przedsiębiorstwa $\mathrm{z}$ elementami układu lokalnego i z otoczeniem.

\section{Uwagi końcowe}

Przedstawione rozważania ilustrują złożony proces funkcjonowania i rozwoju działalności gospodarczej podmiotów gospodarczych oraz instytucji, a także ich wpływ na zmiany struktury wewnętrznej układu lokalnego w nawiązaniu do współczesnych wyzwań rozwoju społeczeństwa informacyjnego. Znajomość tego mechanizmu umożliwia stwarzanie przez władze samorządowe, organizacje społeczne i pozarządowe oraz społeczeństwo układu lokalnego najkorzystniejszych warunków dla rozwoju oraz budowania kapitału społecznego. Naczelnym celem tych działań winno być tworzenie najlepszych warunków dla pobudzania procesów rozwoju gospodarczego, społecznego i kulturowego, kształtowania konkurencyjnych struktur, które będą prowadzić do podnoszenia jakości i poziomu życia społeczeństwa układów lokalnych.

\footnotetext{
${ }^{4} \mathrm{~W}$ jednej z gmin położonych na peryferiach powiatu w latach ożywienia gospodarczego 2007-2010 założono 290 podmiotów gospodarczych, a wykreślono z ewidencji 139 podmiotów. Kryzys w tej gminie zaznaczył się z pewnym opóźnieniem, stąd w 2011 r. założono tylko 24 podmioty gospodarcze, a wykreślono z ewidencji 162 podmioty. Szczególnie silnie proces ten uwidocznił się w budownictwie, w którym liczba firm w tych latach zwiększyła się o 55, a tylko 12 podmiotów zostało wykreślonych, podczas gdy w 2011 r. założono tylko 7 podmiotów, a wkreślono z ewidencji 27 , ale niektóre z tych podmiotów zasiliły szarą strefę. Również w handlu liczba podmiotów odpowiednio wzrosła o 67, a wykreślono 50, natomiast w 2011 r. założono tylko 12 podmiotów, a wykreślono z ewidencji 58. Również założono w tym czasie 10 podmiotów informatycznych, a wykreślono tylko 2, natomiast w $2011 \mathrm{r}$. nie pojawił się żadem nowy podmiot tego typu, a wykreślono 3 podmioty tej kategorii. Tego typu działalność daje również możliwości działania w szarej strefie.
} 
Literatura

References

Brdulak, J., Kulikowski, M. (red.) (2004). Przedsiębiorczość - stymulatorem rozwoju. Instytut Wiedzy SGH, Warszawa.

Czapiński, J. (2015, 8 września). Wywiad A. Kinasiewicza: Prekariat raczej nie wybuchnie. Życie przed nami. Gazeta Wyborcza.

Czarnecka, A., Kłodziński, M. (2010). Przedsiębiorczość pozarolnicza na obszarach wiejskich regionów zielonych płuc. Zagadnienia Ekonomiki Rolnej, 3, 63-78.

Debelle, L., Fircowicz, W., Maj, R., Richard, H., Woźniak, M., Zioło, Z. (1996). Kooperatywa SCARA, być może wzór do naśladowania PAN Oddz. w Krakowie. Prace Komisji Nauk Ekonomicznych, 21.

dmp. (2015, 26 lutego). Nadprodukcja bije rekordy, Rzeczpospolita.

Dobrowolska, M. (red.) (1968). Demograficzno-osadnicze problemy w Tarnobrzeskim Rejonie Siarkowym. Zeszyty Badań Rejonów Uprzemysławianych, 29.

Fierla, I., Kuciński, K. (red.) (1999). Lokalne uwarunkowania przedsiębiorczości. Monografie i opracowania, Warszawa: SGH, 499.

Fierla, I. (red.) (1996). Zmiany uwarunkowań lokalizacji przemystu w Polsce, cz. II. Monografie i opracowania, Warszawa: SGH, 408.

Fierla, I. (red.) (1994). Zmiany uwarunkowań lokalizacji przemysłu w Polsce, cz. I. Monografie i opracowania, Warszawa: SGH, 387.

Fircowicz, W., Maj, R., Woźniak, M., Zioło, Z. (red.) (2006). Rolnictwo w departamencie Aube - rozwój i perspektywy. Studia Regionalne i Lokalne Polski Południowo-Wschodniej, Dzierdziówka Kraków.

Gajewski, E., Świdrak, W. (1962). 130 lat Autosanu, Księga pamiątkowa. Sanok.

Golachowski, S., Zagożdzon, A. (red.) (1974). Dolnośląski Okręg Miedziowy 1960-1970, początki przemian społeczno-ekonomicznych. Seria „Problemy Rejonów Uprzemysławianych”. PAN, Komitet Badań Rejonów Uprzemysławianych, Warszawa: PWN.

Ignar, S. (1962). W sprawie badań naukowych w rejonach uprzemysławianych. Zeszyty Badań Rejonów Uprzemysławianych, 2.

Kamińska W. (2006). Pozarolnicza indywidualna działalność gospodarcza w Polsce w latach 1988-2003. Prace Geograficzne, 203.

Kamińska, W., Heffner, K., (red.) (2010). Kapitał ludzki i społeczny w procesie rozwoju obszarów wiejskich. Studia Komitetu Przestrzennego Zagospodarowania Kraju PAN, CXXVII.

Kamińska, W., Heffner, K., (red.) (2012). Wiejskie rynki pracy - zasoby, aktywizacja, nowe struktury. Studia Komitetu Przestrzennego Zagospodarowania Kraju PAN, CXLV.

Kudełko, J. (2003). Położenie centrów wzrostu społeczno-gospodarczego wschodniego pogranicza jako wyraz kształtującego się ładu przestrzennego. Biuletyn Komitetu Przestrzennego Zagospodarowania Kraju PAN, 205, 176-182.

Kudełko, J. (2013). Uwarunkowania i kierunki rozwoju województw Polski Wschodniej jako regionów słabo rozwiniętych. Studia Komitetu Przestrzennego Zagospodarowania Kraju PAN, CLI.

Lachert, Z., Dembrowska, Z. (1973). Urbanizacja a rolnictwo. Powiat płocki 1960-1965, PAN, Komitet Badań Rejonów Uprzemysławianych, Warszawa.

Maj, R., Woźniak, M., Zioło, Z. (2010). Zarys koncepcji organizacji produkcji PX w strukturze regionalnego kompleksu energetyczno-agrarno-przemysłowego. W: E.R. Grela (red.), Lucerna w żywieniu ludzi i zwierząt. Studia Regionalne i Lokalne Polski Południowo-Wschodniej, Lublin - Sandomierz, 94-102.

Maj, R., Woźniak, M., Zioło, Z. (2012). Gospodarstwa neoprofesjonalne w strukturze kompleksu energetyczno-agrarno-przetrwórczego. W: E.R. Grela, E. Krawczuk-Vasilew (red.), Odnawialne źródła energii w rolnictwie i ochrona środowiska. Studia Regionalne i Lokalne Polski Południowo-Wschodniej, Lublin-Susiec, 10, 25-36. 
Maj, R., Zioło, Z. (1991). Koncepcja organizacji gminnego ośrodka przemysłu rolno-spożywczego. W: Z. Zioło (red.), Problemy przemystu rolno-spożywczego w badaniach geograficznych Centralny Ośrodek Metodyczny Studiów Nauczycielskich w Krakowie, Komisja Geografii PTG, Kraków Warszawa, 143-150.

Możyłowski, P. (2013). Prawno-administracyjne bariery prowadzenia działalności gospodarczej w Polsce w świetle opinii przedsiębiorców oraz raportów Doing Business. Przedsiębiorczość - Edukacja, 9, 48-61.

Nowak, M.J. (2015, 24-27 grudnia). O niechlujności ustawodawcy słów kilka, Rzeczpospolita.

Płaziak, M., Rachwał, T. (2015). „Przedsiębiorczy region” - zarys koncepcji w świetle analizy roli przedsiębiorczości w krajowej strategii rozwoju regionalnego, Przedsiębiorczość - Edukacja, 11, 37-49.

Rachwał, T. (2008). Problematyka badawcza funkcjonowania przedsiębiorstw przemysłowych, Prace Komisji Geografii Przemystu Polskiego Towarzystwa Geograficznego, 11, 53-85.

Rachwał, T. (2009). Rola przedsiębiorstw przemysłowych w kształtowaniu obszarów metropolitalnych. W: Z. Makieła (red.), Potencjalne metropolie ze szczególnym uwzględnieniem Polski Wschodniej, Studia Komitetu Przestrzennego Zagospodarowania Kraju PAN, CXXV, 121-135.

Rachwał, T. (2013). Rola przedsiębiorstw przemysłowych w rozwoju gospodarki opartej na wiedzy. Prace Komisji Geografii Przemystu Polskiego Towarzystwa Geograficznego, 21, 189-211.

Stanisławska, A. (2016, 19 stycznia). Prosto z satelity do Polski, Gazeta Wyborcza, Nauka dla każdego.

Zioło Z. (red.) (1978). Przemiany społeczno-ekonomiczne Tarnobrzeskiego Rejonu Uprzemysławianego. Seria „Problemy Rejonów Uprzemysławianych”, PAN, Komitet Badań Rejonów Uprzemysławianych, Warszawa: PWN.

Zioło, Z. (1991). Zarys koncepcji kompleksu rolniczo-przemysłowego w układzie regionalnym. W: Z. Zioło (red.), Problemy przemysłu rolno-spożywczego w badaniach geograficznych, Centralny Ośrodek Metodyczny Studiów Nauczycielskich w Krakowie, Komisja Geografii PTG, Kraków Warszawa, 131-142.

Zioło, Z. (2010). Kapitał ludzki i społeczny w procesie rozwoju obszarów wiejskich. W: W. Kamińska, K. Heffner (red.), Studia Komitetu Przestrzennego Zagospodarowania Kraju PAN, CXXVII.

Zioło, Z. (2012). Kształtowanie wiejskich rynków pracy na przykładzie wybranych województw. W: W. Kamińska, K. Heffner (red.), Wiejskie rynki pracy - zasoby, aktywizacja, nowe struktury. Studia Komitetu Przestrzennego Zagospodarowania Kraju PAN, CXLV, 106-141.

Zioło, Z., Rachwał, T. (red.) (2010). Procesy transformacji przemysłu i usług w regionalnych i krajowych układach przestrzennych. Prace Komisji Geografii Przemysłu Polskiego Towarzystwa Geograficznego, 15.

Zioło, Z., Rachwał, T. (red.) (2015). Rola przedsiębiorczości w rozwoju społeczno-gospodarczym układów przestrzennych. Przedsiębiorczość - Edukacja, 11.

Zbigniew Zioło, prof. dr hab., Uniwersytet Pedagogiczny im. Komisji Edukacji Narodowej w Krakowie, Instytut Geografii, Zakład Przedsiębiorczości i Gospodarki Przestrzennej. Doktor nauk przyrodniczych, doktor habilitowany i profesor nauk ekonomicznych. Jego zainteresowania badawcze to: gospodarka przestrzenna, geografia ekonomiczna, polityka społeczno-gospodarcza, ekonomika i polityka rozwoju regionalnego.

Zbigniew Zioło, professor, Pedagogical University of Cracow, Institute of Geography, Department of Entrepreneurship and Spatial Management. He holds a ScD title. He is also a professor of Economics. His research interests include: land management, economic geography, socio-economic policies, economics and policies of regional development.

\author{
Adres/Address: \\ Uniwersytet Pedagogiczny im. Komisji Edukacji Narodowej w Krakowie \\ Instytut Geografii \\ Zakład Przedsiębiorczości i Gospodarki Przestrzennej \\ ul. Podchorążych 2 \\ 30-084 Kraków, Polska \\ e-mail: ziolo@up.krakow.pl
}

